\title{
Modelling Surface Water Susceptibility to Pollution Using GIS
}

\author{
Rida Al-Adamat \\ Department of GIS and Remote Sensing, Institute of Earth and Environmental Sciences, Al al-Bayt University, Mafraq, Jordan \\ Email: riddali@aabu.edu.jo
}

How to cite this paper: Al-Adamat, R. (2017) Modelling Surface Water Susceptibility to Pollution Using GIS. Journal of Geographic Information System, 9, 293-308. https://doi.org/10.4236/jgis.2017.93018

Received: May 1, 2017

Accepted: June 12, 2017

Published: June 15, 2017

Copyright $\odot 2017$ by author and Scientific Research Publishing Inc. This work is licensed under the Creative Commons Attribution International License (CC BY 4.0).

http://creativecommons.org/licenses/by/4.0/

\begin{abstract}
This research is an attempt to develop a new GIS index to investigate the surface water susceptibility to pollution (SWSi). In this index, the Weighted Linear Combination techniques within GIS environment was used to calculate the overall surface water susceptibility to pollution scores based on using 6 factors. The model includes 3 natural factors: gradient slope, distance to surface water and soil. Also, it includes 3 man-made activities: urban, agriculture and roads. Each factor was given the appropriate weight and ratings and then the final index was calculated using GIS techniques. The final results showed that the study area $\left(1235 \mathrm{~km}^{2}\right)$ could be classified into low susceptibility with an area of $250 \mathrm{~km}^{2}(20.2 \%)$, moderate susceptibility with an area of $815.5 \mathrm{~km}^{2}$ (66\%), high susceptibility with an area of $166.2 \mathrm{~km}^{2}(13.5 \%)$ and very high susceptibility with an area of $3.3 \mathrm{~km}^{2}(0.3 \%)$.
\end{abstract}

\section{Keywords}

GIS, WLC, Surface Water, Susceptibility, SWSi

\section{Introduction}

The assessment of surface water resources susceptibility to pollution is important for drawing pollution risk maps [1]. There are several studies to investigate surface water susceptibility to pollution worldwide ([1]-[7]). These studies intended to design models and indices to estimate the surface water susceptibility to pollution similar to groundwater vulnerability indices [1]. The major factors used in these studies were slope, land use, land cover, distance to water sources and groundwater contribution, and all these studies used indices to estimate the surface water susceptibility to pollution within GIS environment. GIS is used to quantify sensitivity and potential pollution variables that may affect surface water quality within areas contributing water to surface water sources. 
Jordan is currently one of the poorest countries in the world in terms of water resources. It is characterized by arid climate, with more than $90 \%$ of its area receiving less than $200 \mathrm{~mm}$ rainfall annually. In Jordan, surface water is considered as a major source for household and agricultural usages. It is the major supplier to the agricultural sector and it is the second largest source for household consumption. The annual supply of surface water in Jordan is 214.69 million $\mathrm{m}^{3}$. This precious source of water is not invulnerable to pollution. Surface water resources systems are subject to several man-made pollution impacts. Surface water in Jordan suffers from various sources of pollution. The polluted surface water resources are often those lying within or downstream of urbanized and industrialized areas, as well those surrounding irrigated lands (use and overuse of fertilizers, pesticides and insecticide) ([8] and [9]).

This research is an attempt to modify existing surface water susceptibility to pollution indices based on the available literature. The modified index will be tested on a study area in the Northern part of Jordan.

\section{Research Methods}

\subsection{Study Area}

The selected study area for this research is located in the Northern part of Jordan (Figure 1). It is on the border with Syria and has an area of $1235 \mathrm{~km}^{2}$, which comprises approximately $1.4 \%$ of the total area of Jordan. The study area has several towns and villages (Figure 2) with an urban area of $31.74 \mathrm{~km}^{2}$ which is approximately $2.57 \%$ of the study area. The agricultural area (Figure 2) within the study area is $27.76 \mathrm{~km}^{2}$ which comprises approximately $2.25 \%$ of the study area. The agricultural activities in the area include growing vegetables, fruits and olives [10]. Most of farmers use excessive amounts of fertilizers and pesticides [11].

The study area is mainly flat, where elevation varies between $642 \mathrm{~m}$ above sea level in the South to $1224 \mathrm{~m}$ above sea level near the Syrian border in the North (Figure 3). The average gradient for the study area is less $2 \%$.

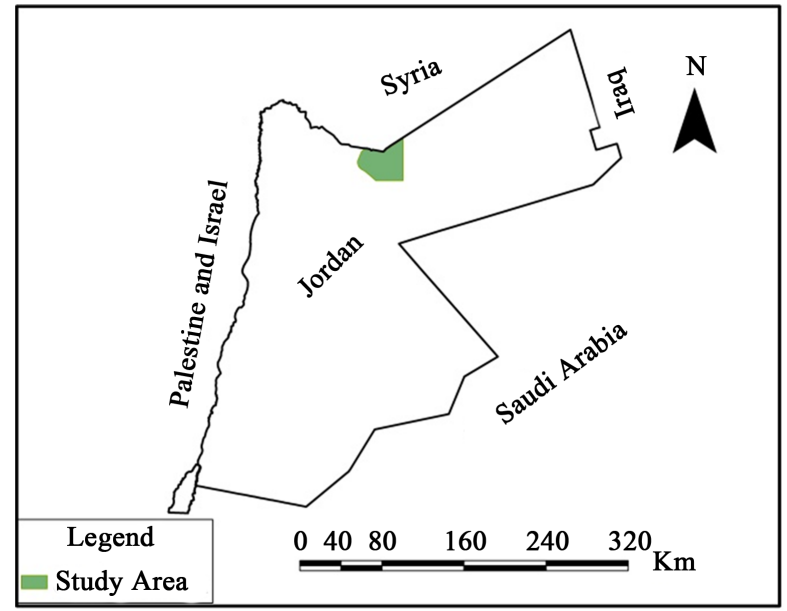

Figure 1. The study area location. 


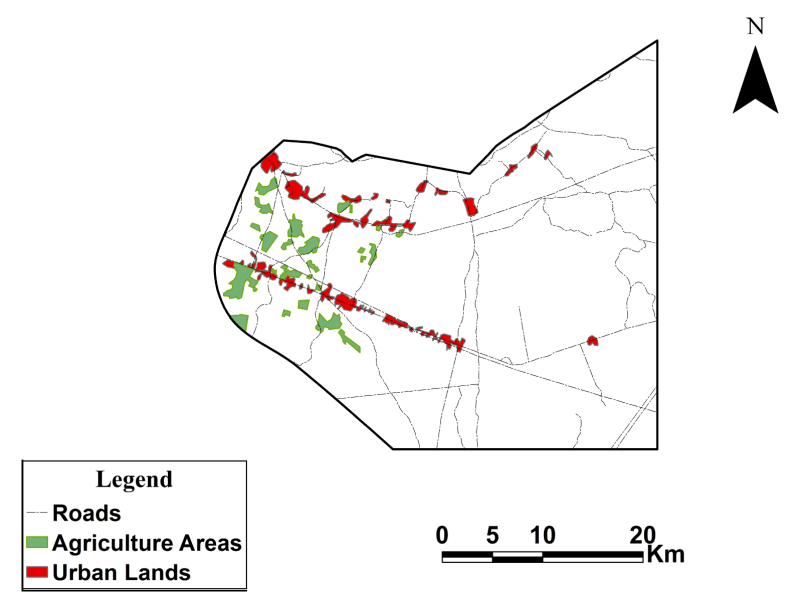

Figure 2. Urban, agricultural lands and roads.

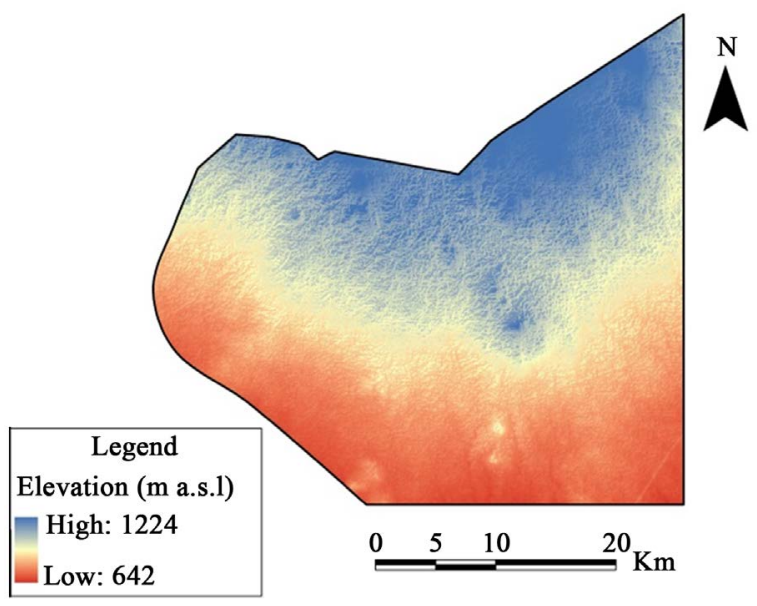

Figure 3. Digital elevation model.

Surface water in the area is mainly from rainfall that occurs between November and March annually. The area receives approximately 250 million cubic meter of rainfall on annual basis. Most of the rainfall is lost due to evaporation (approximately $90 \%$ ), while only $5 \%$ of rainfall generate runoff. The generated runoff flows through the Wadis (streams) that runs mainly from the North towards the South, South East and the South West (Figure 4). Surface water within the study area suffers from various sources of pollution. Among these sources are the followings [11]:

1. The use of fertilizers, pesticides, insecticides and herbicides by farmers in the area.

2. Runoff generated within urban areas which carryout garbage and other pollutant substances to the nearby Wadis.

3. Use of vehicles with oil spills, lead and corroded particles.

\subsection{SWSi Development}

There are few mythologies developed in the USA to investigate surface water susceptibility to pollution. Among these methodologies are the followings: 


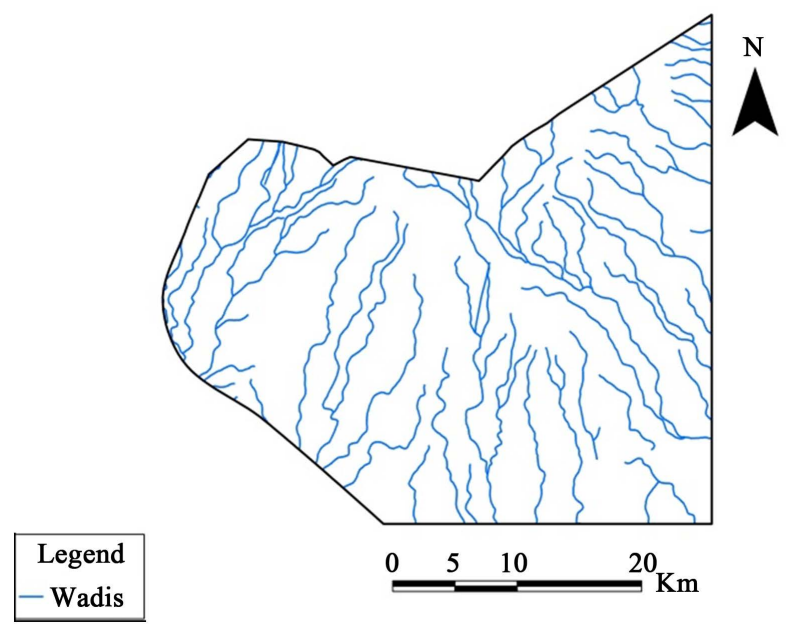

Figure 4. Wadis (Streams) network.

- A methodology by [5] which defines surface water susceptibility to pollution based on 5 factors. These factors include river network, soil, urban distribution, land cover and slope.

- An overlay and index methodology developed by the USGS for rating the characteristics of a watershed [2]. It is based on using 5 factors including average annual precipitation, land surface slope, land cover, land use, and groundwater contribution.

- A methodology developed by [3] that allows the evaluation of the watershed susceptibility to surface water pollution based on major characteristics of a watershed and land uses. It is based on 7 factors including wastewater discharges, recreational land use impacts, agricultural land use impacts, size of watershed, transportation avenues, industrial land use impacts and the amount of vegetation Cover.

- A methodology developed by the Laboratory for Spatial Analysis and the Geosciences at the University of Minnesota-Duluth, USA ([4] and [6]). This methodology was initially developed in 2003 to investigate the surface water susceptibility to pollution from non-point sources. It is based on a fundamental principle that areas with more prone to runoff are capable of transporting suspended sediments to water bodies. Only four intrinsic factors are involved in the estimation of surface-water runoff potential for any given study area using GIS techniques. These factors are gradient slope, distance to water (streams and lakes), land cover and soil properties. Each factor has a weight to reflect its' contribution to surface-water runoff and therefore a general indication of surface water pollution potential.

In this research, a modified methodology will be introduced by having the factors that might influence surface water susceptibility to pollution. The modified index (SWSi) has 6 factors; including gradient slope (\%) (GS), distance to Wadis (streams) (DW), soil clay (\%) (SC), distance to agricultural lands (DA), distance to urban areas (DU) and distance to roads (DR). In order to allocate the appropriate weight for each factor, 7 experts in the field of surface water quality 
from various Jordan Universities and organizations were invited to assign a weight for each factor. Experts were asked to give 6 for the factor that has the highest impact on surface water pollution and 1 for the lowest impact factor. A methodology adopted by [12] was used to come up with a single weight for each factor and overcome the variation between experts' weights allocation. The methodology is based on using both the Mean and Median for experts responses and decides the appropriate weight for each factor. Table 1 summarizes factors weights suggested by the experts. Based on this Table, weights were given to these factors based on each factor contribution to the surface water susceptibility to pollution. The Median value for each factor was selected to represent the appropriate weight for the six factors used in this research. The Mean values also show that the selected weights are reasonable.

The highest weight (6) was given to the gradient slope (GS) (\%), while the lowest weight (1) was given to distance to roads (DR). Table 2 summarizes the classes, weight and ratings for each factor. The justification for using these factors could be summarized as follow:

1. GS: Surface water runoff occurs whenever there is excess water on a slope that cannot be absorbed into the soil or is trapped on the surface. The steeper the slope of a field, the higher potential for runoff [13]. Surface water is more susceptible to pollution when runoff is high and infiltration is low [4]. In this research, GS was classified into 5 classes based on [4] (Table 2).

2. DS: It is an important factor in determining whether surface water is susceptible to pollution or not. In this research a modification to distances suggested by [4] was carried out through the use of meters instead of feet and classify the distance into 5 classes instead of 6 classes (Table 2).

3. SC: High clay contents' soils have several properties that might lead to the movement of pollutants from agricultural lands. Also, surface structure of soils can become degraded in high clay contents' soils. This will lead to the formation of crust which restricts infiltration and increases runoff. Runoff increases when clay soils are wet, due to soil compactness. The runoff may contain pollutants and could affect the surface water quality [14]. In this research, SC were classified into 5 classes as listed in Table 2.

Table 1. Weights given by experts.

\begin{tabular}{cccccccccc}
\hline & \multicolumn{7}{c}{ Experts } & & \\
Factors & Ex1 & Ex2 & Ex3 & Ex4 & Ex5 & Ex6 & Ex7 & Mean & Median \\
\cline { 2 - 7 } & 6 & 6 & 5 & 5 & 6 & 5 & 6 & 5.57 & 6 \\
GS & 5 & 5 & 6 & 6 & 5 & 4 & 5 & 5.14 & 5 \\
SC & 3 & 4 & 4 & 3 & 4 & 6 & 4 & 4.00 & 4 \\
DA & 4 & 3 & 3 & 4 & 3 & 3 & 3 & 3.29 & 3 \\
DU & 1 & 2 & 2 & 2 & 2 & 1 & 2 & 1.71 & 2 \\
DR & 2 & 1 & 1 & 1 & 1 & 2 & 1 & 1.29 & 1 \\
\hline
\end{tabular}


Table 2. Weight and ratings for the SWSi.

\begin{tabular}{|c|c|c|c|c|c|c|c|}
\hline \multicolumn{4}{|c|}{ GS } & \multicolumn{4}{|c|}{ DW } \\
\hline (\%) & Weight & Ratings & $\mathrm{W} \times \mathrm{R}$ & Distance (m) & Weight & Ratings & $\mathrm{W} \times \mathrm{R}$ \\
\hline$>20$ & & 5 & 30 & $\leq 50$ & & 5 & 25 \\
\hline$>10-\leq 20$ & & 4 & 24 & $>50-\leq 100$ & & 4 & 20 \\
\hline$>5-\leq 10$ & 6 & 3 & 18 & $>100-\leq 200$ & 5 & 3 & 15 \\
\hline$>2-\leq 5$ & & 2 & 12 & $>200-\leq 500$ & & 2 & 10 \\
\hline$\leq 2$ & & 1 & 6 & $>500$ & & 1 & 5 \\
\hline \multicolumn{4}{|c|}{ SC } & \multicolumn{4}{|c|}{ DA } \\
\hline Clay (\%) & Weight & Ratings & $\mathrm{W} \times \mathrm{R}$ & Distance $(\mathrm{m})$ & Weight & Ratings & $\mathrm{W} \times \mathrm{R}$ \\
\hline$>30$ & & 5 & 20 & $\leq 500$ & & 5 & 15 \\
\hline$>25-\leq 30$ & & 4 & 16 & $>500-\leq 1000$ & & 4 & 12 \\
\hline$>20-\leq 25$ & 4 & 3 & 12 & $>1000-\leq 2000$ & 3 & 3 & 9 \\
\hline$>15-\leq 20$ & & 2 & 8 & $>2000-\leq 5000$ & & 2 & 6 \\
\hline$\leq 15$ & & 1 & 4 & $>5000$ & & 1 & 3 \\
\hline \multicolumn{4}{|c|}{ DU } & \multicolumn{4}{|c|}{ DR } \\
\hline Distance (m) & Weight & Ratings & $\mathrm{W} \times \mathrm{R}$ & Distance (m) & Weight & Ratings & $\mathrm{W} \times \mathrm{R}$ \\
\hline$\leq 500$ & & 5 & 10 & $\leq 500$ & & 5 & 5 \\
\hline$>500-\leq 1000$ & & 4 & 8 & $>500-\leq 1000$ & & 4 & 4 \\
\hline$>1000-\leq 2000$ & 2 & 3 & 6 & $>1000-\leq 2000$ & 1 & 3 & 3 \\
\hline$>2000-\leq 5000$ & & 2 & 4 & $>2000-\leq 5000$ & & 2 & 2 \\
\hline$>5000$ & & 1 & 2 & $>5000$ & & 1 & 1 \\
\hline
\end{tabular}

4. DA: The agricultural non-point source (NPS) pollution is the leading source of water quality impacts on rivers and lakes [15]. DA were classified into five classes as listed in Table 2.

5. DU: Urban area is one of the most harmful factors affecting surface water health and a major challenge facing watershed managers. Urban runoff affects water chemistry by changing heavy metals and nutrients levels such as phosphorus and nitrogen [16]. DU were classified into five classes as listed in Table 2.

6. DR: Highway run-off could be identified as a major source of diffuse pollution that might contaminate surface water [17]. In this research, DR were classified into five classes as listed in Table 2.

The governing equation (Equation (1)) for the modified index (SWSi) is shown below:

$$
\begin{aligned}
\mathrm{SWSi}= & \mathrm{GSw} \times \mathrm{GSr}+\mathrm{DSw} \times \mathrm{DSr}+\mathrm{SCw} \times \mathrm{SCr} \\
& +\mathrm{DAw} \times \mathrm{DAr}+\mathrm{DUw} \times \mathrm{DUr}+\mathrm{DRw} \times \mathrm{DRr}
\end{aligned}
$$

where GS: Gradient Slope (\%), DS: Distance to Surface Water, SC: Soil Clay (\%), DA: Distance to Agricultural Lands, DU: Distance to Urban Areas, DR: Distance to Roads, w: Weight and r: Ratings. 
The overall index calculation could be classified into 4 susceptibility classes as listed in Table 3 (Low, Moderate, High and Very High).

\subsection{Data Collection}

Dada required for this research were collected from several governmental agencies in Jordan and international agencies. Table 4 describes these dada and their sources.

\section{Data Analysis and Results}

The adopted methodology for analysing the data in this research is based on the use of Weighted Linear Combination (WLC). WLC is a technique of Multi-Criteria Evaluation (MCE) which is based on overlaying layers based on factors weights, factors ratings and/or constraints to create a suitability map [18]. The WLC technique includes the followings steps ([19] [20] [21] [22]):

1. Giving the appropriate ratings for each layer (vector format),

2. Converting all layers into raster format,

3. Multiplying maps weights by their ratings,

4. Combining all layers in order to have the overall suitability scores, and

5. Classifying the outcome into the required classes.

WLC within GIS enviornmnet has been adopted in several applications related to envionmental issues ([23]-[28]). Figure 5 illustrates the adopted methodology for analyzing the GIS data to calculate the final SWSi.

Table 5 summarizes the score values for each factor used to calculate the overall scores for the SWSi. It appears from this table that:

1. The highest scores for the Slope factor (24 and 30) have a small area (5.7\%) of the total study area, while the smallest scores (6 and 12) cover $66.6 \%$ of the study area. This could be attributed to the fact that most of the study area is flat with a slope of less than $5 \%$.

Table 3. SWSi ranges and classes.

\begin{tabular}{ccccc}
\hline Susceptibility Class & Low & Moderate & High & Very High \\
\hline Susceptibility Range & $21-42$ & $42-63$ & $63-84$ & $84-105$ \\
\hline
\end{tabular}

Table 4. The data sets used in this research and their sources.

\begin{tabular}{cccc}
\hline Map Type & Date & Scale/Resolution & Source \\
DEM & 2000 & $\begin{array}{c}1 \text { arc-second } \\
(30 \text { meter })\end{array}$ & The Shuttle Radar Topography Mission (SRTM), USGS \\
Wadis & 1995 & $1: 250,000$ & Royal Jordanian Geographic Centre \\
Soil & 1998 & $1: 250,000$ & Jordan Ministry of Agriculture \\
Roads & 2010 & $1: 250,000$ & Royal Jordanian Geographic Centre \\
Urban & 2016 & $1 \mathrm{~m}$ & Digitizing from Google Earth ${ }^{\oplus} /$ Digital Globe \\
Agriculture & 2016 & $1 \mathrm{~m}$ & Digitizing from Google Earth ${ }^{\oplus / D i g i t a l ~ G l o b e}$ \\
\hline
\end{tabular}




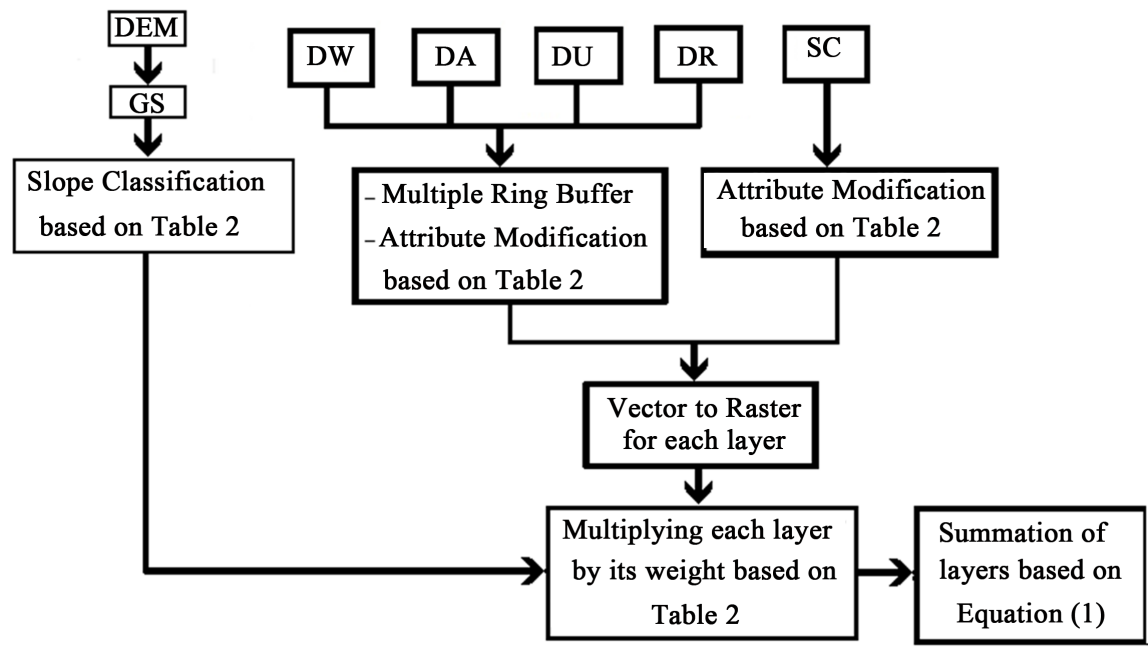

Figure 5. The adopted methodology for data analysis.

Table 5. Summary for the SWSi factors.

\begin{tabular}{cccccc}
\hline GS Scores & 6 & 12 & 18 & 24 & 30 \\
\hline Area $\left(\mathrm{km}^{2}\right)$ & 254.5 & 568.2 & 340.9 & 65.8 & 5.5 \\
\% of area & 20.6 & 46 & 27.6 & 5.3 & 0.4 \\
DW Scores & 5 & 10 & 15 & 20 & 25 \\
Area $\left(\mathrm{km}^{2}\right)$ & 630.5 & 344.5 & 128.8 & 65.4 & 66 \\
\% of area & 51 & 27.9 & 10.4 & 5.3 & 5.3 \\
SC Scores & 4 & 8 & 12 & 16 & 20 \\
Area $\left(\mathrm{km}^{2}\right)$ & 0 & 19.7 & 119.4 & 987.7 & 108.2 \\
\% of area & 0 & 1.6 & 9.7 & 80 & 8.8 \\
DA Scores & 3 & 6 & 9 & 12 & 15 \\
Area $\left(\mathrm{km}^{2}\right)$ & 811.9 & 160.7 & 98.8 & 66.9 & 96.7 \\
\% of area & 65.7 & 13 & 8 & 5.4 & 7.8 \\
DU Scores & 2 & 4 & 6 & 8 & 10 \\
Area $\left(\mathrm{km}^{2}\right)$ & 481.9 & 385 & 161.5 & 85.6 & 121 \\
\% of area & 39 & 31.2 & 13.1 & 6.9 & 9.8 \\
DR Scores & 1 & 2 & 3 & 4 & 5 \\
Area $\left(\mathrm{km}^{2}\right)$ & 0.9 & 209.5 & 326.9 & 285.8 & 412 \\
\% of area & 0.1 & 17 & 26.5 & 23.1 & 33.4 \\
\hline
\end{tabular}

2. The highest scores for the Distance to Wadis (20 and 25) have a small area (10.6\%) of the study area, while the smallest scores (5 and 10) cover (78.9\%) of the study area.

3. The Soil (Clay\%) factor highest scores (16 and 20) cover a large area (88.8\%) of the study area, while the smallest scores (4 and 8 ) cover only $1.6 \%$ of the study area.

4. The distance to Agricultural Lands factor highest scores (12 and 15) cover (13.2\%) of the study area, while the smallest scores (3 and 6) cover $(78.7 \%)$ of 
the study area. This could be attributed by the fact that most of the agricultural activities within the study area are located in the Western part of the study area.

5. The Distance to Urban Areas factor highest scores (8 and 10) cover (16.7\%) of the study area, while the smallest scores (2 and 4 ) cover $(70.2 \%)$ of the study area. This could be explained by the fact that most of the urban areas are concentrated in the Western part of the study area.

6. The Distance to Roads highest scores (4 and 5) cover an area (56.5\%) of the study area, while the smallest scores (1 and 2) cover an area (17.1\%) of the study area.

Figures 6-12 illustrate the factors (weight $\times$ ratings) used in this research to calculate the SWSi.

Based on Equation (1), the six factors shown in Figures 6-11 were summed using the raster calculator in ArcGIS ${ }^{\circ}$ and then classified based on Table 2. Table 6 provides a summary for the final calculation of SWSi. It appears from this table that the low susceptibility areas has an area of $250 \mathrm{~km}^{2}$ which comprises

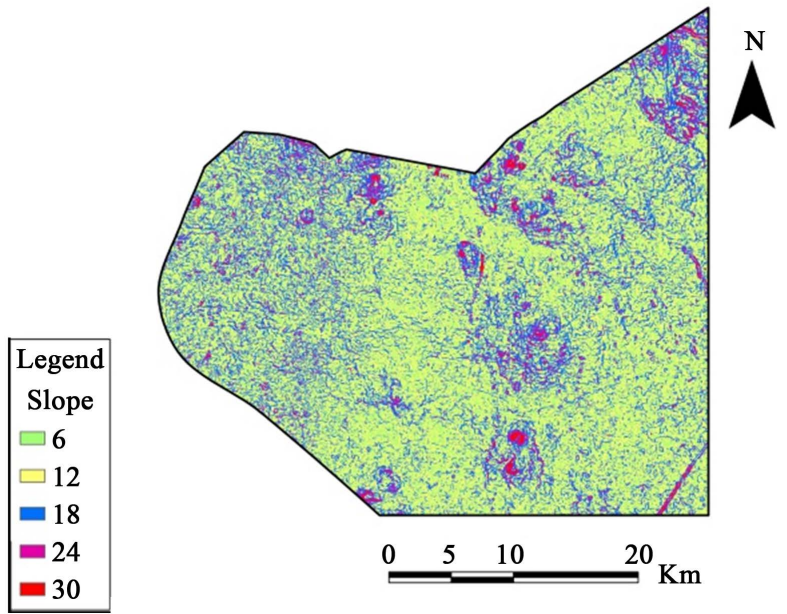

Figure 6. The slope factor.

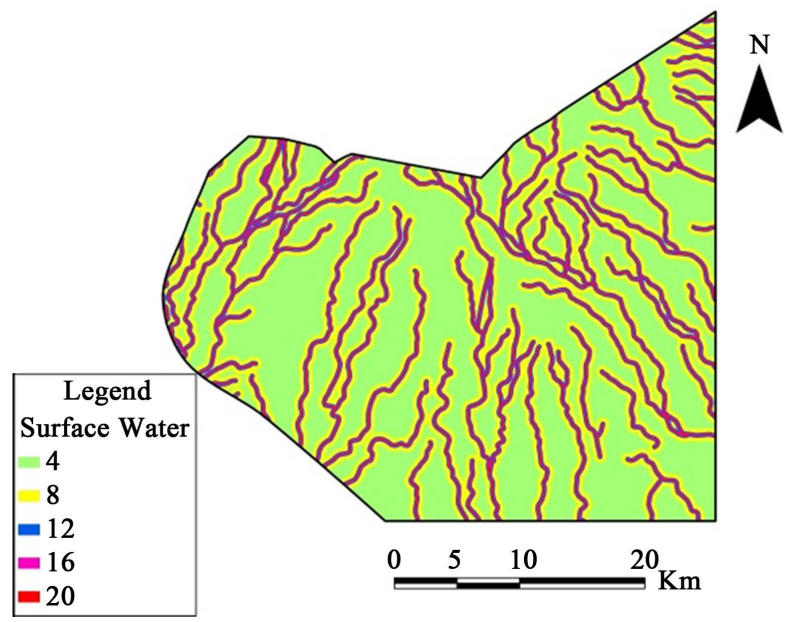

Figure 7. The distance to wadis factor. 


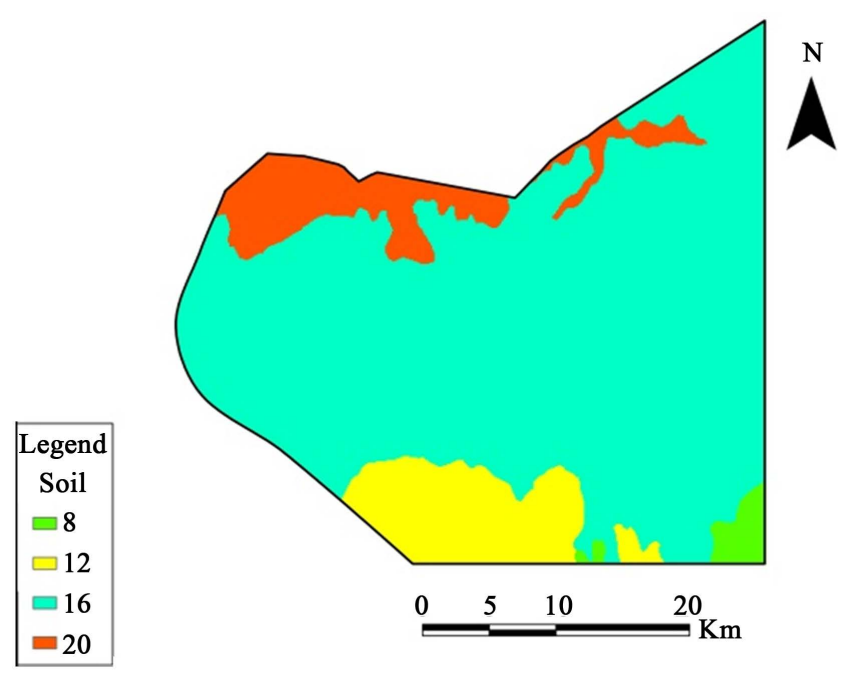

Figure 8. The soil (Clay\%) factor.

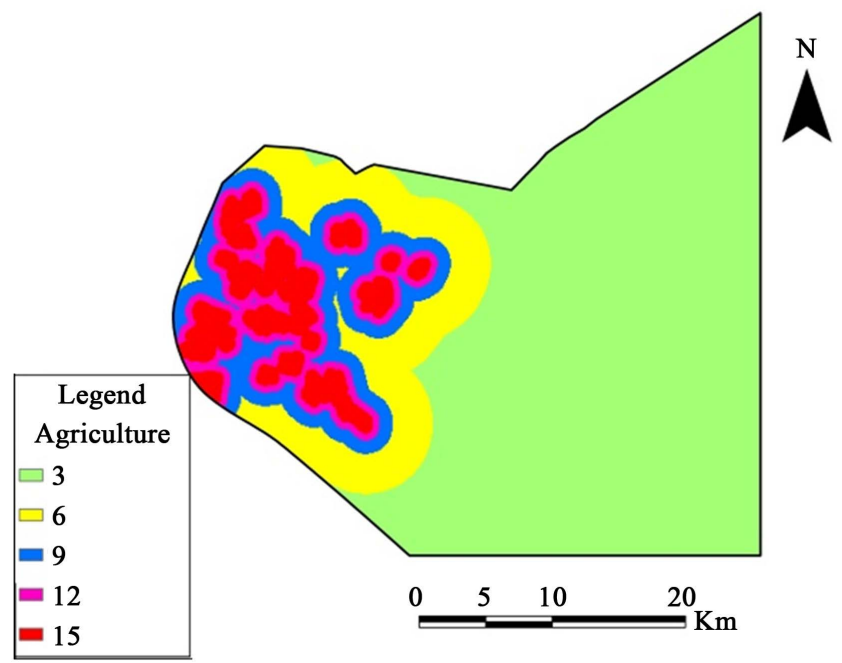

Figure 9. The distance to agricultural lands factor.

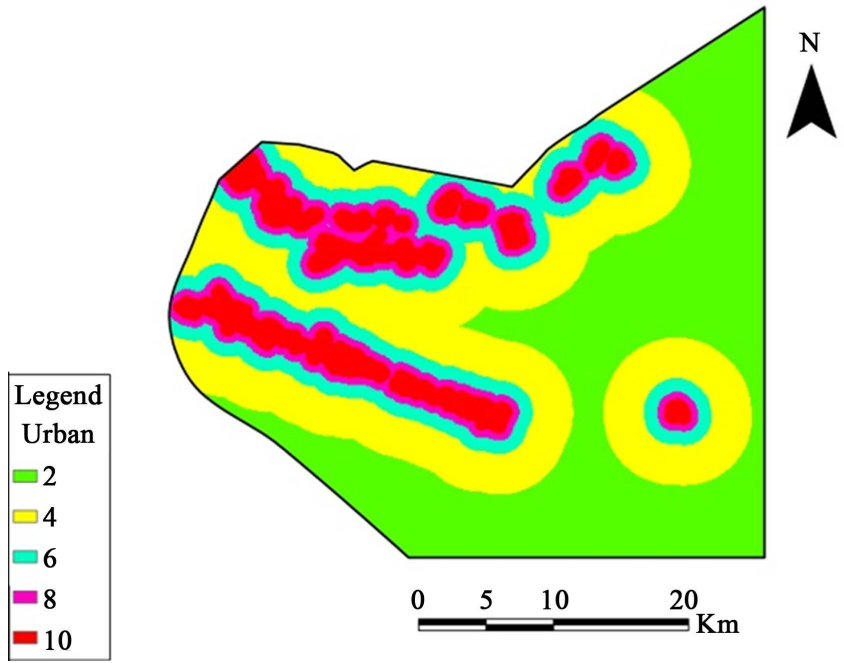

Figure 10. The distance to urban areas factor. 


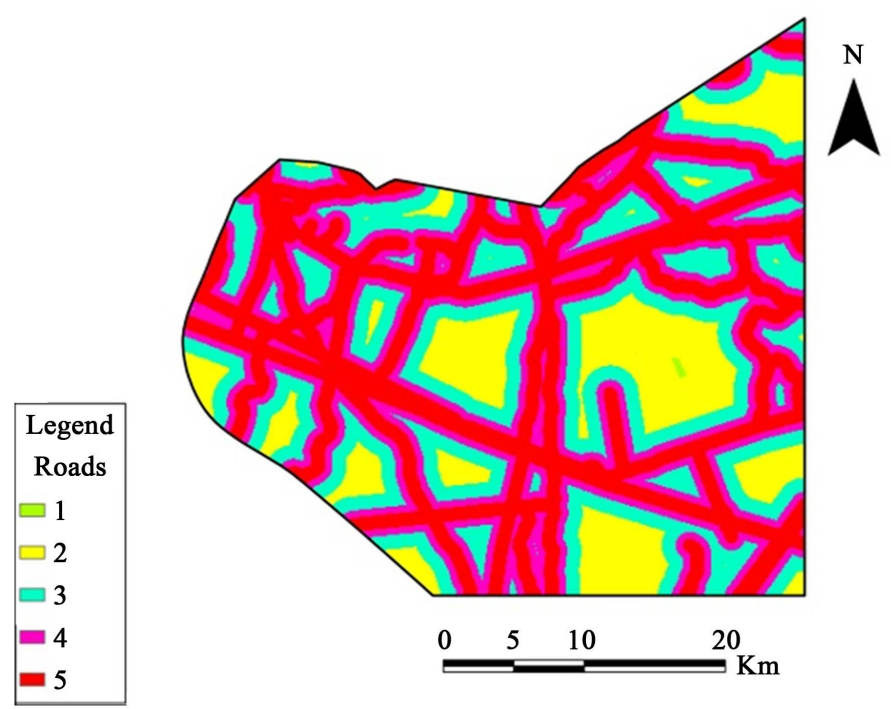

Figure 11. The distance to roads factor.

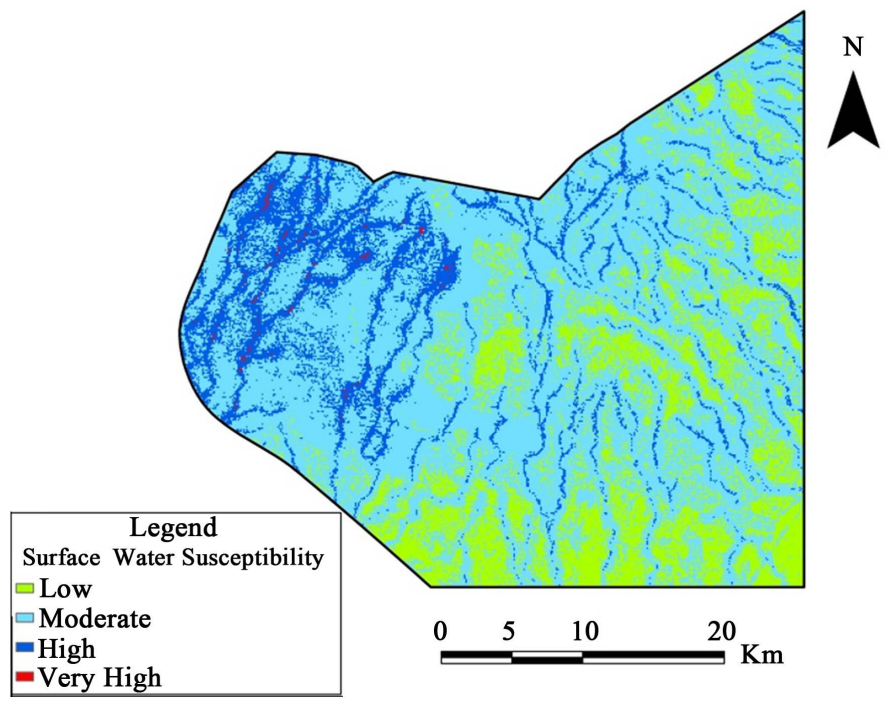

Figure 12. The final SWSi classes.

Table 6. A summary for the SWSi.

\begin{tabular}{ccc}
\hline Class & Area $\left(\mathrm{km}^{2}\right)$ & \% of total area \\
\hline Low & 250 & 20.2 \\
Moderate & 815.5 & 66.0 \\
High & 166.2 & 13.5 \\
Very High & 3.3 & 0.3 \\
Total & 1235 & 100 \\
\hline
\end{tabular}

$20.2 \%$ of the total study area. The areas with high and very high susceptibility have an area of $169.5 \mathrm{~km}^{2}$ which comprises $13.8 \%$ of the study area. The remaining areas have a moderate susceptibility with a total area of $815.5 \mathrm{~km}^{2}$ which comprises $66 \%$ of the total study area. Figure 12 illustrates the final 
classes of the SWSi. It shows that most of the very high and high susceptibility areas are located in the western part of the study area. This is in agreement with the existing urbanization and agricultural activities.

\section{Sensitivity Analysis of the SWSi}

\subsection{Map Removal Analysis}

Table 7 provides a summary statistics for the removal of one statistically significant factor on the SWSi values. This table indicates that the most important factors in the SWSi were DR, DU, DA and DW followed by GS and SC. The highest sensitivity value was associated with DR (47.9), while the lowest sensitivity value (35.8) was associated with SC.

\subsection{Map Removal Sensitivity Analysis}

Based on the map removal sensitivity analysis test developed by [29] and adopted by [30], which was used in this research to identify the sensitivity of each factor in the SWSy map. In this test, Equation (2) was used to calculate the sensitivity index $(S)$ for the factors used in the vulnerability index.

$$
S=\left|(V / N)-\left(V_{x i} / n\right)\right|
$$

where: $S$ is the sensitivity index of the factor;

$V$ is the intrinsic vulnerability index of the method;

$N$ is the total number of factors used to calculate $\mathrm{V}$;

$V_{x i}$ represents the intrinsic vulnerability index obtained after removal of the factor $X$ and

$n$ : the number of factors after removing one factor.

Based on Table 7 that lists the determined partial indices and Equation (2), the sensitivity index was calculated for each factor of the SWSi. Table 8 indicates that SC, GS and DR factors have a strong influence on the SWSi map, while DW, DA and DU factors have a moderate influences on the SWSi map.

\section{Conclusions and Recommendations}

In this research, 6 factors were used to estimate the Surface Water Susceptibility to pollution in a study area in Northern part of Jordan. These factors included slope, distance to Wadis, soil clay (\%), distance to urban areas, distance to agri-

Table 7. The partial index calculated by removing one factor of the SWSi.

\begin{tabular}{ccccc}
\hline Factor Removed & Mean & Min & Max & SD \\
\hline GS & 38.5 & 20 & 75 & 8.86 \\
DW & 42.35 & 21 & 76 & 8.45 \\
SC & 35.8 & 18 & 80 & 9.65 \\
DA & 46.35 & 23 & 90 & 8.89 \\
DU & 47.3 & 24 & 90 & 9.23 \\
DR & 47.9 & 24 & 92 & 10.1 \\
\hline
\end{tabular}


Table 8. Sensitivity index according to the map removal sensitivity analysis test for SWSi map.

\begin{tabular}{ccccc}
\hline \multirow{2}{*}{ Factors } & \multicolumn{4}{c}{ Sensitivity Index } \\
\cline { 2 - 5 } & S Minimum & S Average & S Maximum & Standard Deviation (SD) \\
\hline GS & 0 & 1.03 & 5 & 0.83 \\
DW & 0 & 0.72 & 4 & 0.77 \\
SC & 0 & 1.43 & 3 & 0.58 \\
DA & 0 & 0.83 & 3 & 0.55 \\
DU & 0 & 0.89 & 3 & 0.58 \\
DR & 0 & 0.95 & 3 & 0.56 \\
\hline
\end{tabular}

cultural lands and distance to roads. Each factor was given a weight appropriate to its importance in calculating the SWSi. Also, each factor was given the appropriate ratings at a scale 1 to 5 , where 5 refers to the most susceptible area and 1 for the least susceptible area. The weighted linear combination (WLC) technique within GIS environment was used to calculate the overall score of the SWSi which then was classified into 4 classes (Low, Moderate, High and Very High susceptibility). The results showed that the low susceptible areas have a total area of $250 \mathrm{~km}^{2}(20.2 \%)$. The very high and high susceptible areas have an area of $169.5 \mathrm{~km}^{2}(13.8 \%)$, while the moderate susceptibility areas have an area of 815.5 $\mathrm{km}^{2}(66 \%)$. The sensitivity analysis of the SWSi was carried out to determine the most significant factors. It was found that the most important factors in the SWSi were DR, DU, DA and DW. Also, the map removal sensitivity analysis was carried out to identify the sensitivity of each factor. It was found that SC, GS and DR factors have a strong influence on the SWSi map.

Based on these results, it is concluded that the major factors affecting surface water susceptibility to pollution are addressed in this index. Distances used for ratings urban, agriculture and roads are reasonable since these three factors are major contributors to surface water pollution. Contaminants flushed with rainfall when runoff is generated or passed one of these factors will degrade with distance. Based on that, it is recommended to use the SWSi to estimate surface water susceptibility to pollution. It is also recommended to look for other factors that might contribute to surface susceptibility to pollution. Furthermore, it's recommended to conduct a filed study in order to collect surface water samples at various distances from urban areas, agricultural lands and roads to investigate surface water quality. This might show the pollution of the surface water in reality to verify the outcomes of the SWSi and lead to the modification of given distances at this research.

\section{References}

[1] Diamantino, C., Henriques, M.J., Oliveira, M.M. and Ferreira, J.P.L. (2007) Methodologies for Pollution Risk Assessment of Water Resources Systems. IAHS Publication, 310, 298. 
[2] Eimers, J.L., Weaver, J.C., Terziotti, S. and Midgette, R.W. (2000) Methods of Rating Unsaturated Zone and Watershed Characteristics of Public Water Supplies in North Carolina. U.S. Geological Survey, Water-Resources Investigations, Raleigh, North Carolina, Report 99-4283. Found at: http://water.usgs.gov/pubs/wri/wri994283/

[3] Gallegos, D., Lowance, J. and Thomas, C. (2000) State of New Mexico Source Water Assessment and Protection Program. (Appendix E: WRASTIC Index: WATERSHED VULNERABILITY ESTIMATION USING WRASTIC) Found at: http://www.nmenv.state.nm.us/dwb/Documents/SWAPP_2000.PDF

[4] UMD (the University of Minnesota-Duluth) (2003) Cass County-Ten Mile Lake Association Water Resource Management Tools. Found at: http://www.tenmilelake.org/tmlbirch/hydrology/CASS_TENMILE_REPORT.htm

[5] Harum, T., Saccon, P. and Calasans, N. (2004) Water Resources, Vulnerability Assessment and Quality of Water in Cachoeira Catchement. In: Lourenço, N., Harum, T., Pereira, J.L., Pedronni, L., Lieberei, R., González, A.P., Feoli, E. and Alvim, P.T., Eds., Newsletter ECOMAN, No 3-Decision Support System for Sustainable ECOsystem MANagement in Atlantic Rain Forest Rural Areas. Found at: http://www.uatla.pt/ecoman/

[6] Al-Harahsheh, A., Al-Adamat, R. and Al-Farajat, M. (2010) Potential Impacts on Surface Water Quality from the Utilization of Oil Shale at Lajjoun Area/Southern Jordan Using Geographic Information Systems and Leachability Tests. Energy Sources, Part A: Recovery, Utilization, and Environmental Effects, 32, 1763-1776. https://doi.org/10.1080/15567036.2010.491779

[7] Al-Shabeeb, A.A.R.R. (2010) Investigating the Impacts of King Hussein Bin Talal Development Area (KHBTDA) on Water Resources Using (GIS). Unpublished MSC Dissertation, Al al-Bayt University, Jordan.

[8] Salameh, E. and Bannayan, H. (1993) Water Resources of Jordan, Present Status and Future Potentials. Friedrich Ebert Stiftung, Amman, 183 p.

[9] Salameh, E. (2001) Water Shortages and Environmental Degradation. In: Baban, S. M.J. and Al-Ansari, N.A., Eds., Living with Water Scarcity. Water Resources in Jordan, Badia Region, The Way Forward, Al al-Bayt University, Jordan, 211 p.

[10] Al-Adamat, R.A., Baban, S.M. and Foster, I. (2004) An Examination of Land Use Change Due to Irrigated Agriculture in North-Eastern Jordan Using Geoinformatics. International Journal of Environmental Studies, 61, 337-350. https://doi.org/10.1080/0020723042000199768

[11] Al-Adamat, R. (2003) The Use of Geographical Information Systems and Remote Sensing to Investigate Groundwater Quality in the Azraq Basin Jordan. Unpublished PhD Thesis, Coventry University.

[12] Al-shabeeb, A.R.R. (2015) A Modified Analytical Hierarchy Process Method to Select Sites for Groundwater Recharge in Jordan. Doctoral Dissertation, Department of Geography, University of Leicester.

[13] Ritter, J. and Eng, P. (2012) Soil Erosion-Causes and Effects. Ontario Ministry of Agriculture and Rural Affairs, 12-105.

http://www.omafra.gov.on.ca/english/engineer/facts/12-053.htm

[14] Agriculture and Agri-Food Canada (2014) Soil Texture and Water Quality. http://www.agr.gc.ca/eng/science-and-innovation/agricultural-practices/soil-and-la

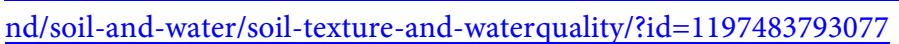

[15] EPA (Environmental Protection Agency) (2005) Protecting Water Quality from Agricultural Runoff. EPA 841-F-05-001. 
http://smithfieldri.com/pdf/engineer/Ag_Runoff_Fact_Sheet.pdf

[16] Riley, M.K. (2008) The Effects of Urbanization on Water Quality: A Biological Assessment of Three Bay Area Watersheds using Benthic Macroinvertebrates as Biological Indicators. Water Quality and Urbanization, 1-20.

[17] Bruen, M., Johnston, P., Quinn, M.K., Desta, M., Higgins, N., Bradley, C. and Burns, S. (2006) Impact Assessment of Highway Drainage on Surface Water Quality. Environmental Protection Agency, Wexford.

http://citeseerx.ist.psu.edu/viewdoc/download?doi=10.1.1.693.820\&rep=rep1\&type $=\mathrm{pdf}$

[18] Eastman, J.R. (1997) Idrisi for Windows, User's Guide, Version 2.0. Clark Labs for Cartographic Technology and Geographic Analysis, Clark University.

[19] Malczewski, J. (2004) GIS-Based Land-Use Suitability Analysis: A Critical Overview. Progress in Planning, 62, 3-65.

[20] Yalcin, A. (2008) GIS-Based Landslide Susceptibility Mapping Using Analytical Hierarchy Process and Bivariate Statistics in Ardesen (Turkey). Comparisons of Results and Confirmations, 72, 1-12.

[21] Al-Adamat, R., Diabat, A. and Shatnawi, G. (2010) Combining GIS with Multicriteria Decision Making for Sitting Water Harvesting Ponds in Northern Jordan. Journal of Arid Environments, 74, 1471-1477.

[22] Al-Adamat, R., AlAyyash, S., Al-Amoush, H., Al-Meshan, O., Rawajfih, Z., Shdeifat, A., Al-Harahsheh, A. and Al-Farajat, M. (2012) The Combination of Indigenous Knowledge and Geo-Informatics for Water Harvesting Sitting in the Jordanian Badia. Journal of Geographic Information System, 4, 366-376.

[23] Pourghasemi, H.R., Moradi, H.R., Aghda, S.F., Gokceoglu, C. and Pradhan, B. (2014) GIS-Based Landslide Susceptibility Mapping with Probabilistic Likelihood Ratio and Spatial Multi-Criteria Evaluation Models (North of Tehran, Iran). Arabian Journal of Geosciences, 7, 1857-1878. https://doi.org/10.1007/s12517-012-0825-x

[24] Latinopoulos, D. and Kechagia, K. (2015) A GIS-Based Multi-Criteria Evaluation for Wind Farm Site Selection. A Regional Scale Application in Greece. Renewable Energy, 78, 550-560.

[25] Junior, R.V., Varandas, S.G.P., Fernandes, L.S. and Pacheco, F.A.L. (2015) Multi Criteria Analysis for the Monitoring of Aquifer Vulnerability: A Scientific Tool in Environmental Policy. Environmental Science \& Policy, 48, 250-264.

[26] Singh, L.K., Jha, M.K. and Chowdary, V.M. (2017) Multi-Criteria Analysis and GIS Modeling for Identifying Prospective Water Harvesting and Artificial Recharge Sites for Sustainable Water Supply. Journal of Cleaner Production, 142, 1436-1456.

[27] Alvarado, A., Esteller, M.V., Quentin, E. and Expósito, J.L. (2016) Multi-Criteria Decision Analysis and GIS Approach for Prioritization of Drinking Water Utilities Protection Based on Their Vulnerability to Contamination. Water Resources Management, 30, 1549-1566. https://doi.org/10.1007/s11269-016-1239-4

[28] Bagdanavičiūtè, I. and Valiūnas, J. (2013) GIS-Based Land Suitability Analysis Integrating Multi-Criteria Evaluation for the Allocation of Potential Pollution Sources. Environmental Earth Sciences, 68, 1797-1812. https://doi.org/10.1007/s12665-012-1869-7

[29] Lodwick, W.A., Monson, W. and Svoboda, L. (1990) Attribute Error and Sensitivity Analysis of Map Operations in Geographical Information Systems: Suitability Analysis. International Journal of Geographical Information Systems, 4, 413-428. 
https://doi.org/10.1080/02693799008941556

[30] Al-Adamat, R. and Al-Shabeeb, A.A.R. (2017) A Simplified Method for the Assessment of Groundwater Vulnerability to Contamination. Journal of Water Resource and Protection, 9, 305-321. https://doi.org/10.4236/jwarp.2017.93020

Submit or recommend next manuscript to SCIRP and we will provide best service for you:

Accepting pre-submission inquiries through Email, Facebook, LinkedIn, Twitter, etc. A wide selection of journals (inclusive of 9 subjects, more than 200 journals) Providing 24-hour high-quality service User-friendly online submission system Fair and swift peer-review system Efficient typesetting and proofreading procedure Display of the result of downloads and visits, as well as the number of cited articles Maximum dissemination of your research work

Submit your manuscript at: http://papersubmission.scirp.org/

Orcontact jgis@scirp.org 